\title{
Aortic constriction induces hypertension and cardiac hypertrophy via (pro)renin receptor activation and the PLC- $\beta 3$ signaling pathway
}

\author{
JUNYAN WU ${ }^{1}$, CONG ZHANG $^{2}$, CHUANJUN LIU ${ }^{1}$, AIHUA ZHANG ${ }^{1}$, \\ AN LI $^{1}$, JINGJUN ZHANG ${ }^{3}$ and YANLING ZHANG ${ }^{1,3}$ \\ ${ }^{1}$ Institute of Cardiovascular Diseases, Taian Maternal and Child Health Hospital, Taian, Shandong 271000; \\ ${ }^{2}$ Department of Endocrinology, Peking Union Medical College Hospital, Beijing 100730; ${ }^{3}$ Department of Neurology, \\ Taishan Medical University, Taian, Shandong 271000, P.R. China
}

Received March 30, 2018; Accepted October 4, 2018

DOI: $10.3892 / \mathrm{mmr} .2018 .9653$

\begin{abstract}
The (pro)renin receptor $[(\mathrm{P}) \mathrm{RR}]$ serves an important role in cardiovascular complications. However, the precise mechanisms of $(P) R R$ in the heart remain obscure. The authors hypothesized that overexpression of (P)RR would be associated with activation of the relevant signal pathway which could lead to organ injury. The aim of the present study was to test the role of cardiac (P)RR and its potential signaling pathway components including phospholipase C (PLC), protein kinase C (PKC), extracellular signal-regulated kinase (ERK)1/2 and Raf-1 proto-oncogene, serine/threonine kinase (Raf-1). Hypertension and cardiac hypertrophy were induced by partial abdominal aortic ligation in Sprague-Dawley rats. The expression levels of cardiac (P)RR, PLC- $\beta 3$, PKC, ERK1/2 and Raf-1 were measured following administration of the handle region peptide (HRP) and PLC- $\beta 3$ inhibitor U73122. The expression of (P)RR and PLC- $\beta 3$ significantly increased in the left ventricle $(\mathrm{P}<0.05)$. Levels of PKC- $\alpha$, ERK1/2 and Raf-1 in the heart rose significantly $(\mathrm{P}<0.05)$. HRP and U73122 significantly decreased the levels of cardiac (P)RR and PLC- $\beta 3$. Furthermore, levels of PKC- $\alpha$, ERK1/2 and Raf-1 were also decreased $(\mathrm{P}<0.05)$. Cardiac parameters, blood pressure and plasma Angiotensin (Ang) I and Ang II levels were altered significantly $(\mathrm{P}<0.05)$. The results demonstrated that hypertension induced by aortic restriction activated the (P)RR in the heart. This action led to hypertension and cardiac hypertrophy via the (P)RR-PLC- $\beta 3$-PKC-ERK1/2-Raf-1 signaling pathway. These results provide a mechanism by which elevated $(\mathrm{P}) \mathrm{RR}$
\end{abstract}

Correspondence to: Professor Yanling Zhang, Institute of Cardiovascular Diseases, Taian Maternal and Child Health Hospital, 386 Longtan Road, Taian, Shandong 271000, P.R. China

E-mail: lzhang98@hotmail.com

Key words: hypertrophy, hypertension, renin, receptor, heart levels in hypertension may contribute to the development of cardiac remodeling.

\section{Introduction}

Features of myocardial remodeling include cardiomyocyte hypertrophy, apoptosis, fibrosis and alterations in cardiovascular function (1). The renin-angiotensin (Ang) system (RAS) serves an important role in cardiac remodeling. Ang II induces cardiac hypertrophy and fibrosis in hypertension (2-4). Furthermore, a newly discovered member of the RAS, (pro) renin receptor $[(\mathrm{P}) \mathrm{RR}]$, is a novel drug target due to its crucial involvement in cardiovascular injury $(5,6)$.

Binding of (pro)renin/renin to (P)RR increases Ang I formation from angiotensinogen and induces Ang II-independent intracellular signaling (7). The experimental evidence for the role of (P)RR was obtained from studies of progressive nephropathy developed in human- $(\mathrm{P}) \mathrm{RR}$-transgenic rats following the occurrence of hypertension (8-10). Rats overexpressing the (P)RR gene in vascular smooth muscle cells develop high blood pressure and a high level of plasma aldosterone (9). Direct local intramyocardial adenovirus-mediated gene delivery demonstrated that (P)RR triggers the deterioration of cardiac function and participates in extracellular matrix remodeling (11). However, AT1 receptor blockade does not prevent the decrease in the ejection fraction, suggesting that (P)RR-induced worsening of cardiac function is independent of Ang II generation. Furthermore, rats with (P)RR overexpression develop glomerulosclerosis with increased extracellular signal-regulated kinase 1/2 (ERK1/2) phosphorylation (12). Also, human prorenin activates p38 mitogen activated protein kinase and phosphorylates heat shock protein-27 in neonatal rat cardiomyocytes (12). These combined results suggest that Ang II-independent effects of (P)RR are important in the development of cardiovascular diseases.

These studies demonstrate that in rats with hypertension, elevated (P)RR expression levels may correlate with cardiovascular complications by a direct effect exerted by $(\mathrm{P}) \mathrm{RR}$ signaling mechanisms. However, the precise mechanisms of the (P)RR signaling in the heart remain obscure. 
Previous experiments have used an inhibitory peptide termed the handle region peptide (HRP), which binds competitively to the (P)RR with prorenin (13-15). Ichihara et al (13) reported that infusion of HRP decreases cardiac Ang II levels and attenuates cardiac fibrosis in a diabetic rat model of nephropathy. However, Feldt et al (14) did not find that HRP prevents (pro)renin signaling in a double-transgenic rat model. The discrepancy between these reports may be due to the different animal models and different doses of HRP used in experiments. Since prorenin is highly species-specific, different HRPs exist for different rat models in which there are different prorenin and renin levels (15). Therefore, it is necessary to further investigate the effects of HRP on (P)RR and its signals in various animal models. In the present study, HRP was used in an aortic constricted rat model to investigate effects on cardiac remodeling and the (P)RR signaling pathway.

Therefore, the overall goal of the present study was to test the hypothesis that overexpression of cardiac (P)RR is induced by aortic constriction, resulting in activation of the phospholipase C (PLC)- $\beta 3$-protein kinase C (PKC)-ERK1/2-Raf-1 proto-oncogene, serine/threonine kinase (Raf 1) signaling pathway, thereby inducing cardiac remodeling and hypertension.

\section{Materials and methods}

Animals. Male Sprague-Dawley rats weighing 180-200 g (aged 6 weeks, Shandong Lukang Co., Ltd., Jining, China) were housed in a temperature-controlled $\left(24-26^{\circ} \mathrm{C}\right.$ with $60 \%$ humidity) animal facility (12-h light/dark cycle) with ad libitum access to rat chow and tap water. All animal experiments were performed in accordance with the NIH guidelines (Guide for the Care and Use of Laboratory Animals) and were approved by the Animal Ethics Committee of Taishan Medical University (Taian, China).

Experimental protocols. A total of 75 male Sprague-Dawley rats were randomized to the abdominal aortic constriction and sham-operated groups, as described previously (16). Briefly, animals were anesthetized with sodium pentobarbitone (60 mg/kg, intraperitoneally). Sham-operated animals underwent the same procedure without the aortic ligation [control (C), n=15]. Aortic ligation surgery was undertaken in the rest of the rats. Following recovery, they were randomly allocated to the following groups: i) vehicle [aortic ligation (AL), $n=15$ ]; ii) PLC- $\beta 3$ inhibitor U73122 (Selleck Chemicals Houston, TX, USA; U, n=15) $40 \mu \mathrm{g} / \mathrm{kg} /$ day for 4 weeks; iii) (P)RR inhibitor HRP (Phoenix Pharmaceuticals Inc., Burlingame, CA, USA; $\mathrm{H}, \mathrm{n}=15) 4 \mu \mathrm{g} / \mathrm{kg} /$ day for 4 weeks; and iv) both U73122 and HRP combined at the same doses $(\mathrm{U}+\mathrm{H}, \mathrm{n}=15)$ delivered by a subcutaneous mini-pump.

Blood pressure was measured by the tail-cuff method using Blood Pressure Meter (Softron BP-2012A; Beijing Incorporated, Beijing, China) as described previously $(16,17)$.

Following 4 weeks of treatment, the animals were sacrificed by an overdose of sodium pentobarbitone $(100 \mathrm{mg} / \mathrm{kg}$, intraperitoneally). Blood plasma was collected and hearts were dissected and weighed. The left ventricle (LV) was dissected and snap-frozen in isopentane/dry ice for immunohistochemical studies. The remainder of the $\mathrm{LV}$ was preserved at $-80^{\circ} \mathrm{C}$ for reverse transcription-polymerase chain reaction (RT-PCR) and western blot analysis.

Ang I and Ang II assays. Plasma samples were obtained by centrifugation of blood $(2,000 \mathrm{xg})$ at $4^{\circ} \mathrm{C}$ for $10 \mathrm{~min}$. Plasma Ang I and Ang II concentration ( $\mathrm{ng} / \mathrm{ml}$ ) was quantitatively determined by a radioimmunoassay using commercial kits (cat. no. 10059; Puer Weiye Biotech Ltd., Beijing, China) based on methods described previously (16-18).

Measurement of (P)RR, PLC- $\beta 3, P K C-\alpha, P K C-\varepsilon, E R K 1 / 2$ and Raf-1 mRNAs. Total RNA was extracted from heart tissue using TRIzol ${ }^{\circledR}$ (Invitrogen; Thermo Fisher Scientific, Inc., Waltham, MA, USA). RT-PCR was carried out using PCR Reagent kits with 5X M-MLV buffer and dNTPs (Takara Bio, Inc., Otsu, Japan). Template cDNA was prepared using reverse transcriptase (Takara Bio, Inc.). Detailed information on all primers used in the study, including (P)RR, PLC- $\beta 3$, PKC- $\alpha$, PKC- $\varepsilon$, ERK1/2 and Raf-1 is presented in Table I. The products of PCR were size-fractionated on $1 \%$ agarose gels and detected by ethidium bromide staining. Following quantification of band intensities using a Bio-Rad Gel Documentation System (version 4.6; Bio-Rad Laboratories, Inc., Hercules, CA, USA), the relative steady-state level of mRNA was calculated following normalizing to GAPDH (as internal reference gene) and presented as gene/GAPDH for each sample in experimental groups. In each experimental run the mRNA value for the control heart was given a value of 1 and the amount of target gene mRNA in the experimental hearts was expressed as a ratio of this value $(16,17)$. Then, the comparison of relative quantity of mRNA was statistically conducted between groups.

Western blot analysis. Protein was extracted with Radioimmunoprecipitation Assay buffer from heart tissue and subjected to western blot analysis. Briefly, following protein concentration determination via the bicinchoninic acid method, a total of $30 \mu \mathrm{g}$ protein was loaded per lane, separated in a $10 \%$ SDS-PAGE and transferred to polyvinylidene membranes. The membranes were blocked at room temperature for $3 \mathrm{~h}$ with 5\% fat-free milk in TBS $/ 0.5 \%$ Tween-20, then incubated with primary antibodies (Abcam, Cambridge, USA) against (P)RR (cat. no. ab40790), PLC- $\beta 3$ (cat. no. ab14247), PKC- $\alpha$ (cat. no. ab32376) and Raf-1 (cat. no. ab137435; all diluted to 1:1,200), and primary antibodies (Cell Signaling Technology, Inc., Danvers, MA, USA) against PKC- $\varepsilon$ (cat. no. 2683) and ERK1/2 (cat. no. 4695; both diluted to $1: 1,000$, at $4^{\circ} \mathrm{C}$ overnight respectively, followed by horseradish peroxidase-conjugated secondary antibody (cat. no. ZB-2301; Beijing Zhongshan Jinqiao Biotech Co., Ltd., Beijing, China; 1:5,000) for $2 \mathrm{~h}$. Chemiluminescence was detected with an enhanced chemiluminescence kit (Pierce; Thermo Fisher Scientific, Inc.) and subsequent exposition to Hyperfilm (GE Healthcare, Chicago, IL, USA). The signals of blots were quantified by using a Bio-Rad gel documentation system (version 4.6) (Bio-Rad Laboratories, Inc.). GAPDH (analyzed using an antibody from OriGene Technologies, Inc., Beijing, China) served as the loading control. The protein expression levels of (P)RR, PLC- $\beta 3$, PKC- $\alpha$, PKC- $\varepsilon$, ERK1/2 and Raf-1 were calculated in relation to GAPDH. The value of 
Table I. Primers used in reverse transcription-quantitative polymerase chain reaction.

\begin{tabular}{|c|c|c|}
\hline Primers & Sequence $\left(5^{\prime}-3^{\prime}\right)$ & $\begin{array}{l}\text { Length } \\
\text { (bp) }\end{array}$ \\
\hline$(\mathrm{P}) \mathrm{RR}$ & $\begin{array}{l}\text { F: CATAAGCATCTCGCCAAGG } \\
\text { R: ACCAGGGATGTGTCGAATGA }\end{array}$ & 224 \\
\hline PLC- $\beta 3$ & $\begin{array}{l}\text { F: GGTCCTACCACTTCCTCCACTA } \\
\text { R: GCСТCСТCТTCСТССТTCAC }\end{array}$ & 317 \\
\hline PKC- $\alpha$ & $\begin{array}{l}\text { F: GTTTACCCGGCCAACGACT } \\
\text { R: GTGGGTTGCTTGAAGAAGCG }\end{array}$ & 134 \\
\hline PKC- $\varepsilon$ & $\begin{array}{l}\text { F: CAAGGTGTAGCGAGTGAGTGG } \\
\text { R: CGGACTGTTGGTCTTCTGCT }\end{array}$ & 314 \\
\hline ERK1 & $\begin{array}{l}\text { F: TATCAACACCACCTGCGACC } \\
\text { R: ATGATCTCTGGGGCTCGGTA }\end{array}$ & 129 \\
\hline ERK2 & $\begin{array}{l}\text { F: TTGTTCCCAAACGCTGACTC } \\
\text { R: TAGGTAAGTCGTCCAGCTCC }\end{array}$ & 187 \\
\hline Raf-1 & $\begin{array}{l}\text { F: AGCACCACCCTCTTTCACAA } \\
\text { R: AGCATCACCTCACTGGCTTC }\end{array}$ & 432 \\
\hline GAPDH & $\begin{array}{l}\text { F: CAGTGCCAGCCTCGTCTCAT } \\
\text { R: AGGGGCCATCCACAGTCTTC }\end{array}$ & 595 \\
\hline
\end{tabular}

the control (sham-operated group) was expressed as 1 and then values from other experimental groups were compared with this to determine fold-change for each protein $(16,17)$.

(P)RR immunohistochemistry. Sections of unfixed hearts were embedded in PolyFreeze Tissue Freezing Medium (Polysciences, Warrington, PA, USA) and snap-frozen $\left(-35^{\circ} \mathrm{C}\right)$ in isopentane/dry ice. Cryostat sections, $7 \mu \mathrm{m}$ thick, were cut and fixed in cold $4 \%$ paraformaldehyde for $30 \mathrm{~min}$ at $4{ }^{\circ} \mathrm{C}$. The sections were incubated with the dilution of primary antibody against (P)RR (Abcam) at dilution of 1:200 in PBS solution. Following washing with PBS, they were incubated with peroxidase-conjugated anti-rabbit IgG (goat polyclonal, 1:5,000; cat. no. ZF-0311; OriGene Technologies, Inc., Beijing, China) for $1 \mathrm{~h}$ at $4^{\circ} \mathrm{C}$. The color was developed with $0.05 \%$ 3,3'-diaminobenzidine tetrahydrochloride (DAB) and $0.01 \%$ $\mathrm{H}_{2} \mathrm{O}_{2}$. Myocyte (P)RR staining was assessed by measuring the area of stained tissue within a given field. A total of 20 fields were analyzed for each animal. The immunostaining area of $(\mathrm{P}) \mathrm{RR}$ was obtained in a given area and expressed as a percentage of the entire image (16-18).

Statistical analysis. All data are expressed as the mean \pm standard error of the mean. Statistical significance of MAP, (P)RR, PLC- $\beta 3$, PKC- $\alpha$, PKC- $\varepsilon$, ERK1/2 and Raf- 1 and plasma Ang I, Ang II data was analyzed by a Repeated Measures analysis of variance in SPSS (version 11.0; SPSS, Inc., Chicago, IL, USA) followed by post-hoc multiple comparison tests with the Least Significant Difference post hoc test. $\mathrm{P}<0.05$ was considered to indicate a statistically significant differences.

\section{Results}

Inhibitors of $(P) R R$ and PLC- $\beta 3$ attenuate hypertension and cardiac hypertrophy induced by aortic constriction in vivo. Mean arterial pressure (MAP) and heart rate changes are presented in Table II. Aortic constriction increased MAP $(\mathrm{P}<0.05)$, but HRP, U73122, or both inhibitors combined, significantly decreased MAP compared with the aortic ligation group $(\mathrm{P}<0.05)$. Compared with aortic restricted (AL) rats, HRP and U73122 significantly decreased MAP $(\mathrm{P}<0.05)$. There was no difference in heart rate between groups.

There was no significant difference in body weight among groups (Table III). However, heart, left and right ventricle and atrial wall weights were significantly increased in hypertensive rats from aortic constriction $(\mathrm{P}<0.05)$. HRP, U73122 and the combination of the two significantly reduced the whole heart, left and right ventricle, and atrial weight $(\mathrm{P}<0.05)$, respectively. The ratios of heart, left and right ventricle weight to body weight demonstrated a significant difference in these animals $(\mathrm{P}<0.05$; Table III).

Aortic constriction significantly affects levels of Ang I and Ang II in the circulation. Alterations of plasma Ang I and Ang II concentration are presented in Table II. The concentration of Ang I and Ang II significantly increased in AL rats $(\mathrm{P}<0.05)$. Administration of HRP, U73122 and the combination of the two significantly decreased plasma Ang I and Ang II levels $(\mathrm{P}<0.05)$ compared with both control and $\mathrm{AL}$ rats, respectively.

Increase in cardiac PLC-b3-PKC-ERK1/2-Raf-1 signaling expression induced by aortic constriction is reduced following inhibition of HRP and U73122. Cardiac (P)RR mRNA significantly increased in aortic constricted rats $(\mathrm{P}<0.05)$. HRP treatment, U73122 treatment or the two combined downregulated $(\mathrm{P}) \mathrm{RR}$ mRNA in the heart $(\mathrm{P}<0.05$; Fig. 1A) respectively, compared with AL animals. A similar alteration in cardiac (P)RR protein level was observed (Fig. 1B). Compared with controls, PLC- $\beta 3$ mRNA and its protein levels increased in AL rats, and the levels were significantly reduced with treatment of HRP or U73122 or the two combined in rats, compared with controls and AL animals ( $\mathrm{P}<0.05$; Fig. $1 \mathrm{C}$ and $\mathrm{D})$.

Immunohistochemistry results for $(\mathrm{P}) \mathrm{RR}$ are presented in Fig. 2. In the sham-operated rats, $(\mathrm{P}) \mathrm{RR}$ was expressed in cardiomyocytes at a basal level (Fig. 2A and F). Cardiac (P)RR immunostaining level was significantly upregulated in AL rats $(\mathrm{P}<0.05$; Fig. $2 \mathrm{~B}$ and $\mathrm{F})$. U73122, HRP and the combined treatment of the two significantly decreased cardiac $(\mathrm{P}) \mathrm{RR}$ levels compared with AL and control animals, respectively $(\mathrm{P}<0.05$; Fig. 2C-F).

Cardiac PKC- $\alpha$ mRNA was significantly increased in AL rats $(\mathrm{P}<0.05)$ and was significantly reduced by administration of U73122, HRP and both reagents combined ( $\mathrm{P}<0.05$; Fig. 3A). Cardiac PKC- $\alpha$ protein levels significantly increased in $\mathrm{AL}$ group $(\mathrm{P}<0.05)$ and were significantly suppressed in $\mathrm{U} 73122$, HRP or combined groups ( $\mathrm{P}<0.05$; Fig. 3B).

Cardiac PKC- $\varepsilon$ mRNA level was significantly reduced in $A L$ rats $(P<0.05)$, however it was significantly elevated by treatment of $\mathrm{U} 73122(\mathrm{P}<0.05)$ and both treatments combined $(\mathrm{P}<0.05$; Fig. 3C). The alteration in cardiac $\mathrm{PKC}-\varepsilon$ protein 
Table II. Blood pressure, heart rate, Ang I and Ang II concentration in groups of rats.

\begin{tabular}{|c|c|c|c|c|c|}
\hline $\mathrm{BP}$ and $\mathrm{HR}$ & $\mathrm{C}$ & $\mathrm{AL}$ & U73122 & HRP & $\mathrm{U}+\mathrm{H}$ \\
\hline MAP (mmHg) & $100 \pm 3$ & $155 \pm 5^{\mathrm{a}}$ & $128 \pm 5^{\mathrm{a}, \mathrm{b}}$ & $131 \pm 6^{\mathrm{a}, \mathrm{b}}$ & $126 \pm 6^{\mathrm{a}, \mathrm{b}}$ \\
\hline HR (beats $\min ^{-1}$ ) & $316 \pm 14$ & $304 \pm 11$ & $332 \pm 16$ & $328 \pm 15$ & $334 \pm 17$ \\
\hline \multicolumn{6}{|l|}{ Ang I and Ang II } \\
\hline Ang I $\left(\right.$ ng ml $\left.^{-1}\right)$ & $21.8 \pm 1.2$ & $32.5 \pm 2.8^{\mathrm{a}}$ & $16.8 \pm 1.0^{\mathrm{a}, \mathrm{b}}$ & $20.5 \pm 0.9^{\mathrm{a}, \mathrm{b}}$ & $10.2 \pm 0.7^{\mathrm{a}, \mathrm{b}}$ \\
\hline Ang II $\left(\mathrm{ng} \mathrm{ml}^{-1}\right)$ & $5.8 \pm 0.3$ & $10.2 \pm 0.8^{\mathrm{a}}$ & $5.2 \pm 0.5^{\mathrm{a}, \mathrm{b}}$ & $4.5 \pm 0.2^{\mathrm{a}, \mathrm{b}}$ & $4.3 \pm 0.5^{\mathrm{a}, \mathrm{b}}$ \\
\hline
\end{tabular}

Results are expressed as the mean \pm standard error of the men. ${ }^{\mathrm{a}} \mathrm{P}<0.05$ vs. control group; ${ }^{\mathrm{b}} \mathrm{P}<0.05$ vs. AL group. $\mathrm{C}$, control ( $\left.\mathrm{n}=15\right)$; $\mathrm{AL}$, aortic ligation $(n=15)$; U, U73122 ( $n=15)$; H, handle region peptide/HRP $(n=14)$; U+H, U73122+HRP $(n=15)$; BP, blood pressure; HR, heart rate; MAP, mean arterial pressure; Ang, angiotensin.

Table III. Body and heart weights in groups of rats.

\begin{tabular}{lccccc}
\hline & $\mathrm{C}$ & $\mathrm{AL}$ & $\mathrm{U} 73122$ & $\mathrm{HRP}$ & $\mathrm{U}+\mathrm{H}$ \\
\hline $\begin{array}{l}\text { Body weight }(\mathrm{g}) \\
\text { Cardiac parameters }\end{array}$ & $242 \pm 5$ & $239 \pm 4$ & $244 \pm 5$ & $241 \pm 4$ & $239 \pm 7$ \\
HW $(\mathrm{g})$ & $0.921 \pm 0.062$ & $0.969 \pm 0.035^{\mathrm{a}}$ & $0.823 \pm 0.029^{\mathrm{a}, \mathrm{b}}$ & $0.845 \pm 0.044^{\mathrm{a}, \mathrm{b}}$ & $0.812 \pm 0.024^{\mathrm{a}, \mathrm{b}}$ \\
LV $(\mathrm{g})$ & $0.709 \pm 0.031$ & $0.758 \pm 0.021^{\mathrm{a}}$ & $0.689 \pm 0.048^{\mathrm{a}, \mathrm{b}}$ & $0.648 \pm 0.022^{\mathrm{a}, \mathrm{b}}$ & $0.663 \pm 0.035^{\mathrm{a}, \mathrm{b}}$ \\
RV (g) & $0.165 \pm 0.008$ & $0.175 \pm 0.009^{\mathrm{a}}$ & $0.156 \pm 0.005^{\mathrm{a}, \mathrm{b}}$ & $0.159 \pm 0.002^{\mathrm{a}, \mathrm{b}}$ & $0.146 \pm 0.002^{\mathrm{a}, \mathrm{b}}$ \\
AW $(\mathrm{g})$ & $0.037 \pm 0.001$ & $0.044 \pm 0.002^{\mathrm{a}}$ & $0.034 \pm 0.004^{\mathrm{a}, \mathrm{b}}$ & $0.035 \pm 0.005^{\mathrm{b}}$ & $0.035 \pm 0.007^{\mathrm{a}, \mathrm{b}}$ \\
HW/BW g/(100 g) & $0.379 \pm 0.007$ & $0.408 \pm 0.005^{\mathrm{a}}$ & $0.336 \pm 0.01^{\mathrm{a}, \mathrm{b}}$ & $0.350 \pm 0.006^{\mathrm{a}, \mathrm{b}}$ & $0.338 \pm 0.008^{\mathrm{a}, \mathrm{b}}$ \\
LV/BW g/(100 g) & $0.292 \pm 0.004$ & $0.318 \pm 0.006^{\mathrm{a}}$ & $0.281 \pm 0.005^{\mathrm{a}, \mathrm{b}}$ & $0.267 \pm 0.002^{\mathrm{a}, \mathrm{b}}$ & $0.277 \pm 0.004^{\mathrm{a}, \mathrm{b}}$ \\
RV/BW g/(100 g) & $0.068 \pm 0.006$ & $0.073 \pm 0.004^{\mathrm{a}}$ & $0.063 \pm 0.003^{\mathrm{a}, \mathrm{b}}$ & $0.065 \pm 0.004^{\mathrm{a}, \mathrm{b}}$ & $0.061 \pm 0.004^{\mathrm{a}, \mathrm{b}}$ \\
AW/BW g/(100 g) & $0.015 \pm 0.003$ & $0.019 \pm 0.003^{\mathrm{a}}$ & $0.013 \pm 0.005^{\mathrm{a}, \mathrm{b}}$ & $0.014 \pm 0.004^{\mathrm{b}}$ & $0.012 \pm 0.005^{\mathrm{a}, \mathrm{b}}$ \\
\hline
\end{tabular}

Results are expressed as the mean \pm standard error of the mean. ${ }^{a} \mathrm{P}<0.05$ vs. control group; ${ }^{b} \mathrm{P}<0.05$ vs. AL group. $\mathrm{C}$, control ( $\left.\mathrm{n}=15\right)$; $\mathrm{AL}$, aortic ligation ( $n=15)$; U, U73122 ( $n=15)$; H, handle region peptide/HRP ( $n=14)$; U+H, U73122+HRP ( $n=15)$; HW, heart weight; LV, left ventricle weight; $\mathrm{RV}$, right ventricle weight; $\mathrm{AW}$, atrial weight.

expression level was similar to the trend demonstrated in mRNA expression level $(\mathrm{P}<0.05$; Fig. 3D).

With aortic constriction, the level of ERK1/2 mRNA in the heart significantly increased $(\mathrm{P}<0.05)$. Treatment with U73122, HRP and the two reagents combined significantly downregulated ERK1/2 mRNA (P<0.05; Fig. 4A). Furthermore, cardiac ERK1/2 protein levels were reduced by administration of both inhibitors ( $\mathrm{P}<0.05$; Fig. 4B).

Aortic constriction increased Raf-1 mRNA levels $(\mathrm{P}<0.05)$. U73122, HRP and both treatments combined decreased Raf-1 mRNA ( $\mathrm{P}<0.05)$, compared with AL rats (Fig. 4C). Cardiac Raf-1 protein levels increased in AL rats and were then significantly downregulated in U73122, HRP and combined treatment groups $(\mathrm{P}<0.05$; Fig. 4D).

\section{Discussion}

The present study, to the best of the author's knowledge, has described for the first time, an association between aortic restriction by partial abdominal aortic ligation leading to an increase in (P)RR and PLC- $\beta 3$ expression and cardiac hypertrophy (as evidenced by an increase in heart weight). Administration of HRP and U73122 downregulated the expression of (P)RR and PLC- $\beta 3$, which indicated an association between the activities of cardiac (P)RR and PLC- $\beta 3$. The results obtained from the current hypertensive animal model suggested a role for (P)RR and PLC- $\beta 3$ in the pathophysiology of heart diseases. The present study demonstrated that aortic restriction upregulated the levels of (P)RR in the heart through the enhancement of PLC- $\beta 3$, PKC, ERK1/2 and Raf-1.

A number of studies have suggested involvement of (P)RR in the development of cardiovascular diseases $(19,20)$. However, less is known about the mechanism by which the level of (P)RR expression is regulated in the heart in hypertension. Assessment of the mechanisms associated with aortic restriction-induced (P)RR expression will help better understanding of the role of the receptor in the heart in the pathophysiology of hypertension complications and has the potential for development of novel therapeutic tools for treatment of heart damage.

While the expression of (P)RR and PLC- $\beta 3$ is upregulated by aortic restriction, the results of the present study also demonstrated that plasma Ang I and Ang II levels increased in the circulation, which suggested that catalytic capacity in angiotensinogen conversion leads to increased Ang II formation. The (pro)renin receptor (P)RR has been considered to 
A
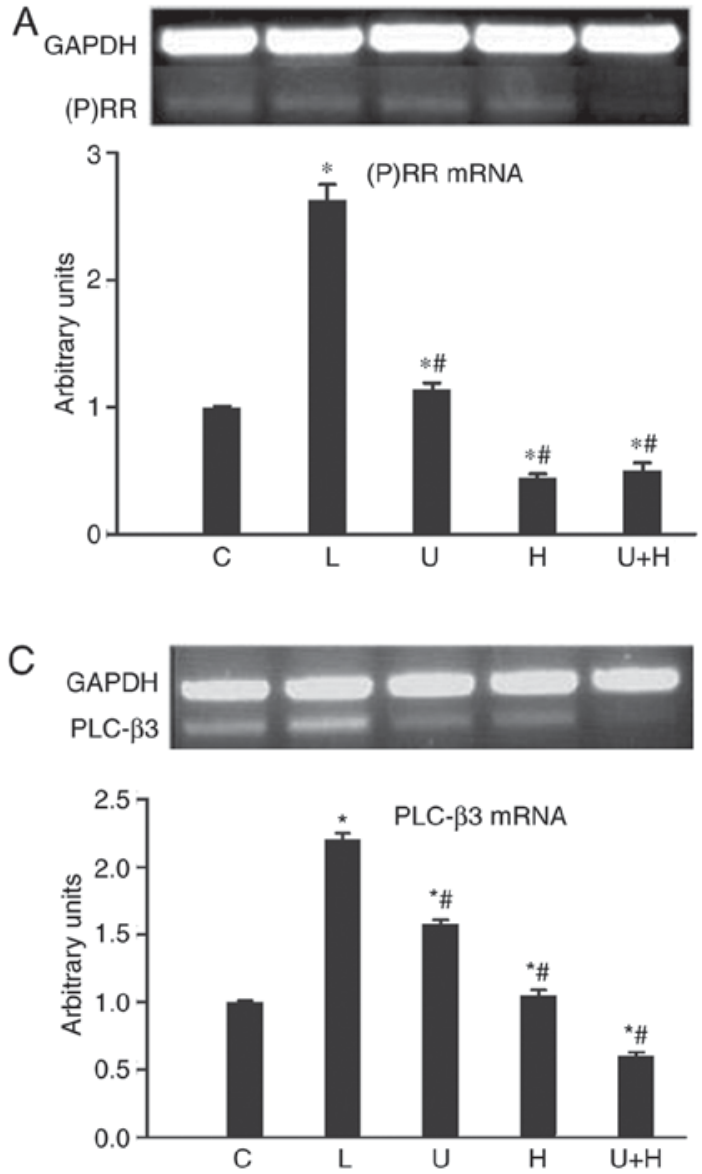

B

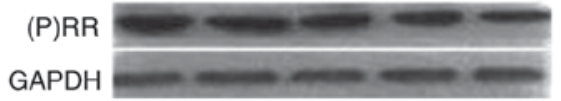

$42 \mathrm{kDa}$

$37 \mathrm{kDa}$
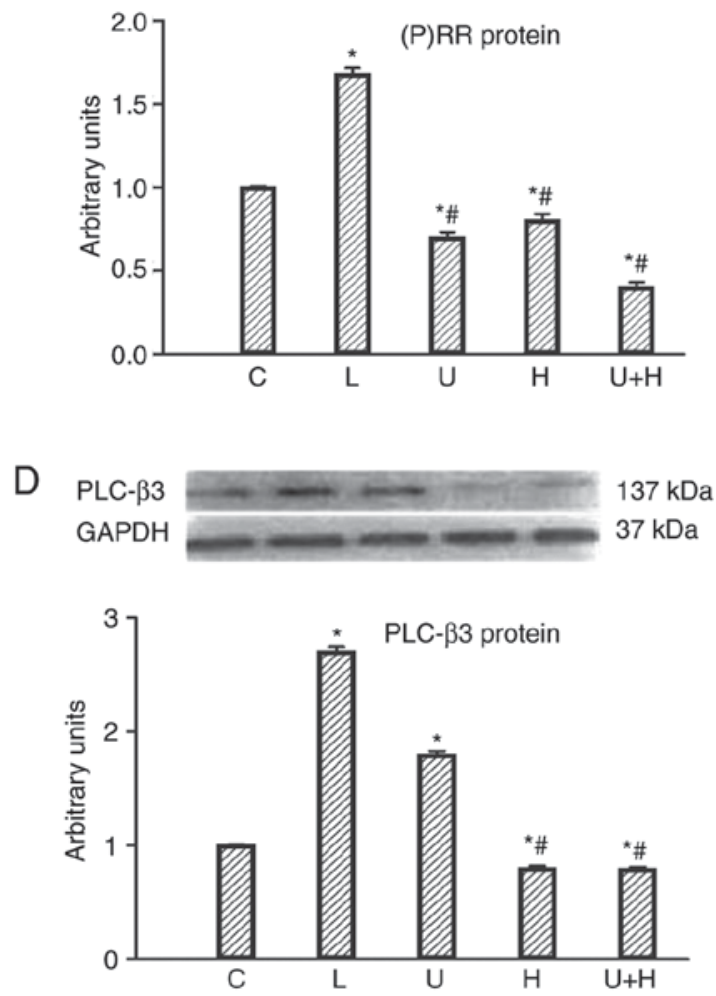

Figure 1. Levels of (A) cardiac (P)RR mRNA (B) and its protein, and (C) PLC- $\beta 3$ mRNA and (D) its protein in the C ( $n=15), A L,(n=13), U$ ( $n=13), H R P$ $(\mathrm{H}, \mathrm{n}=14)$ or $\mathrm{U} 73122+\mathrm{HRP}(\mathrm{U}+\mathrm{H}, \mathrm{n}=13)$-treated rats. Data are expressed as the mean \pm standard error of the mean. ${ }^{*} \mathrm{P}<0.05 \mathrm{vs}$. control; ${ }^{*} \mathrm{P}<0.05 \mathrm{vs}$. AL. AL, aortic ligation; (P)RR, (pro)renin receptor; U73122; H, handle region peptide/HRP; U+H, U73122 + HRP; PLC, phospholipase C; C, control.
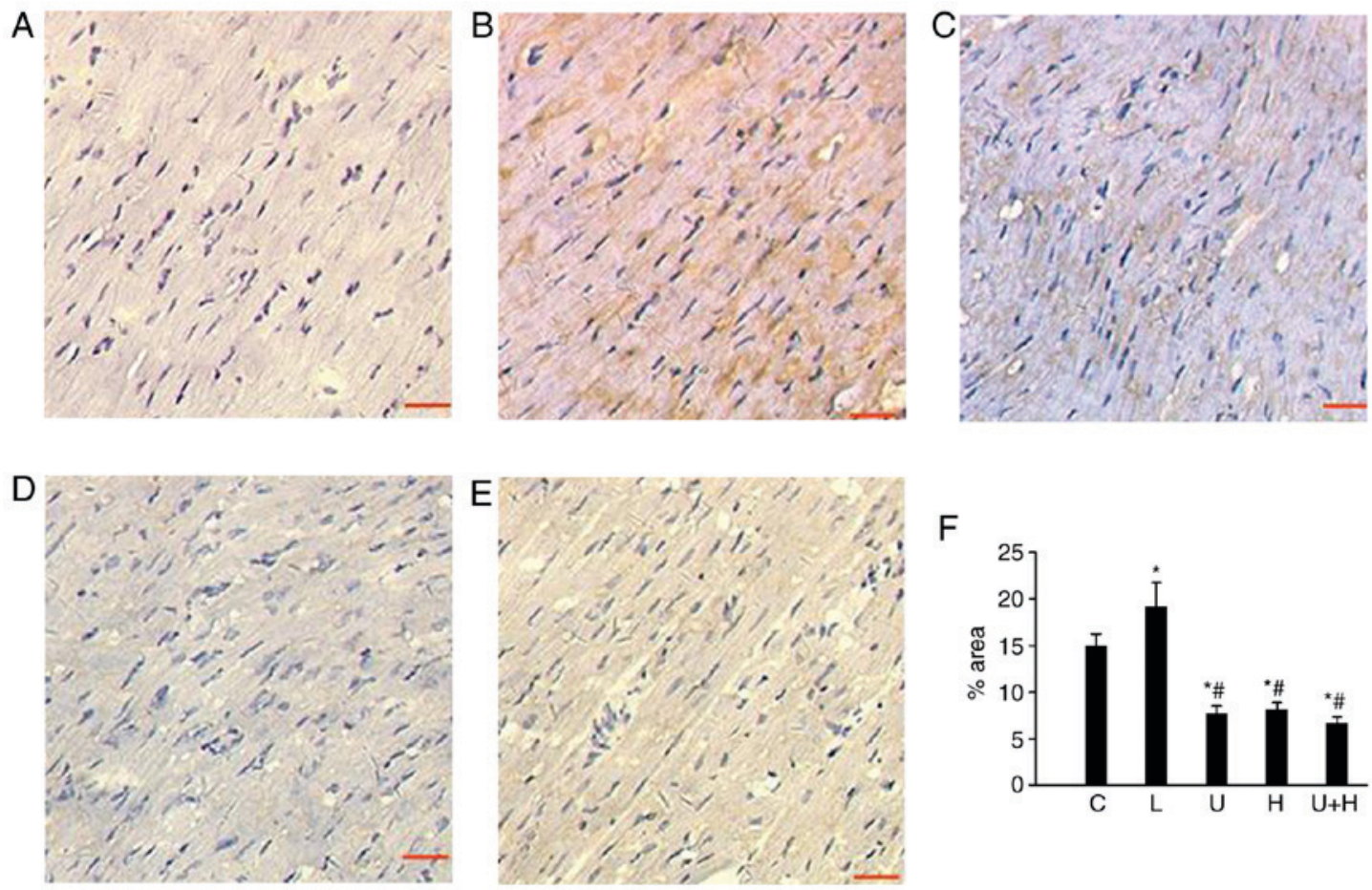

Figure 2. Light microscopic images of (P)RR immunohistochemical labeling (brown staining) of cardiomyocytes in the left ventricle of (A) C, (B) AL, (C) U, (D) $\mathrm{H}$ or (E) U+H-treated rats. Scale bar=100 $\mu \mathrm{m}$; Magnification, $\mathrm{x} 40$. (F) Quantification of the light microscope images are expressed as the mean \pm standard error of the mean. ${ }^{*} \mathrm{P}<0.05$ vs. C; ${ }^{\text {P }}<0.05$ vs. AL. $\mathrm{n}=15$ each group. AL, aortic ligation; (P)RR, (pro)renin receptor; U73122; H, handle region peptide/HRP; $\mathrm{U}+\mathrm{H}, \mathrm{U} 73122+\mathrm{HRP} ; \mathrm{C}$, control. 

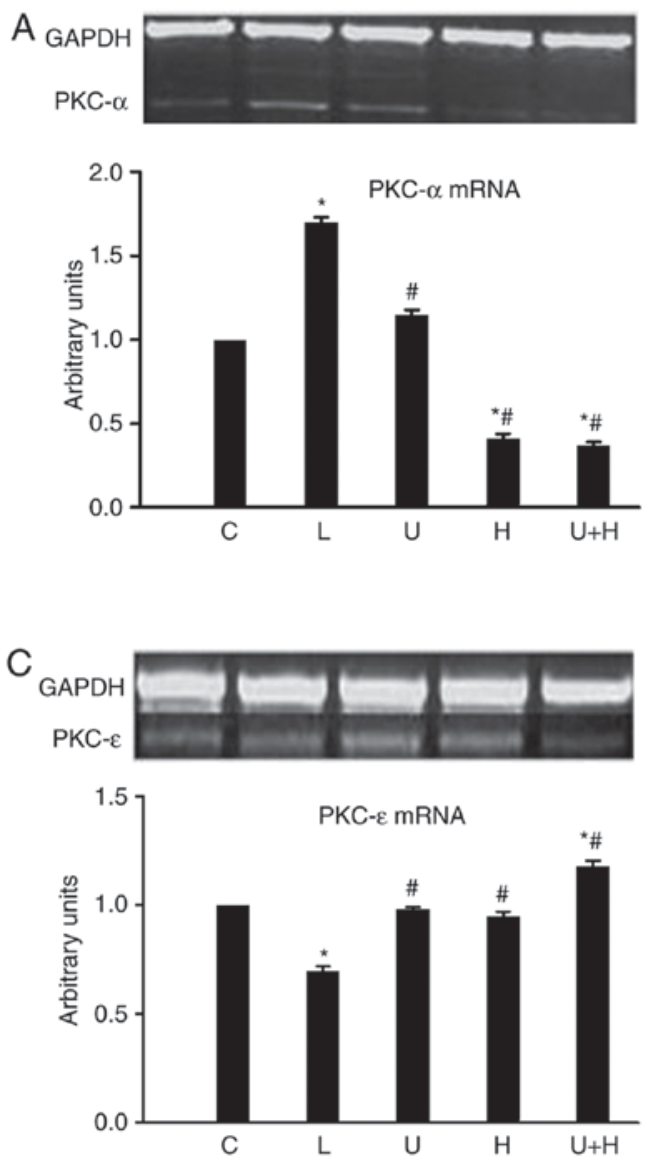

B
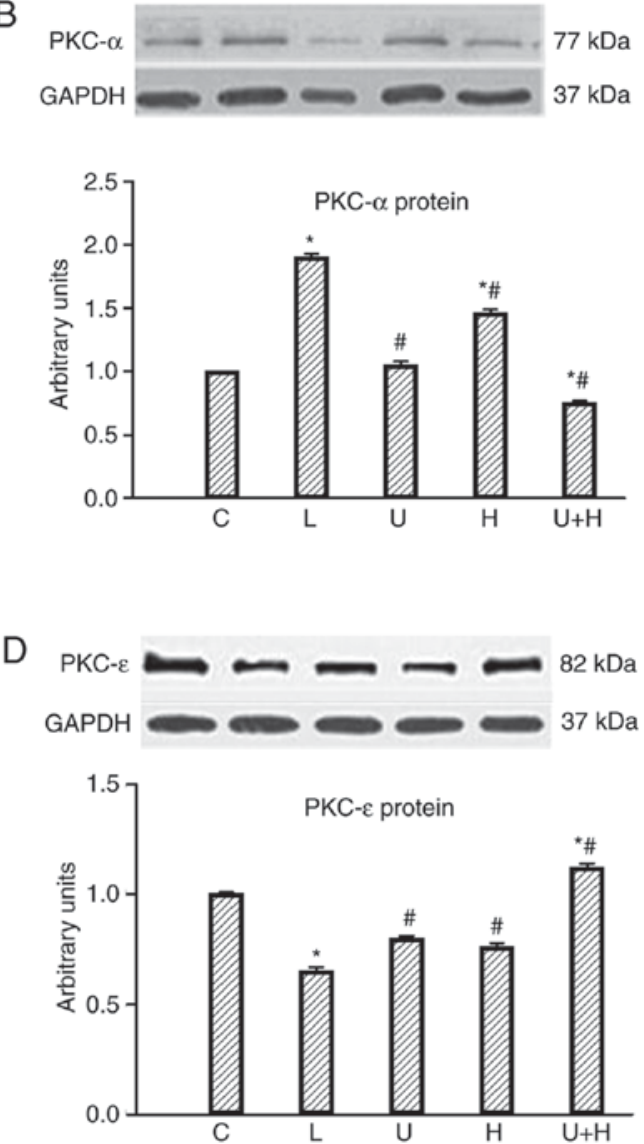

Figure 3. Levels of (A) cardiac PKC- $\alpha$ mRNA and (B) its protein, and (C) PKC- $\varepsilon$ mRNA (D) and its protein in C ( $n=14), A L(n=12)$, $U$ ( $n=13), H(n=12)$ or $U+H$ $(\mathrm{n}=13)$-treated rats. Data are expressed as the mean \pm standard error of the mean. ${ }^{*} \mathrm{P}<0.05$ vs. $\mathrm{C}$; ${ }^{\mathrm{P}}<0.05$ vs. AL. AL, aortic ligation; ( $\left.\mathrm{P}\right) \mathrm{RR}$, (pro)renin receptor; U73122; H, handle region peptide/HRP; U+H, U73122 + HRP; C, control; PKC, protein kinase C.

function by two different mechanisms: i) Prorenin bound to this receptor generates Ang I and then Ang II; and ii) prorenin/renin binding to $(\mathrm{P}) \mathrm{RR}$ leads to the activation of the signaling pathways followed by upregulation of hypertrophic genes independent of Ang II (21-24).

The present study demonstrated that intracellular PKC, ERK1/2 and Raf-1 signals enhanced (P)RR expression, as inhibition of the receptor and PLC- $\beta 3$ attenuated not only the aortic restriction-induced expression of this receptor, but also the expression levels of PKC- $\alpha$, ERK1/2 and Raf- 1 in the heart. The level of cardiac PKC- $\alpha$ decreased following administration of U73122, accompanied with a reduction of cardiac hypertrophy, suggesting that PKC- $\alpha$ may act as a regulator of myocyte hypertrophic growth. Furthermore, the present study demonstrated that blockade of the receptor by HRP increased the PKC- $\varepsilon$ level, implicating that PKC- $\varepsilon$ may serve an opposite role to PKC- $\alpha$ in the regulation of the receptor expression in the signal pathway. These results are consistent with previous reports of increased PKC- $\alpha$ activity in a signaling network that programs developmental and pathological cardiomyocyte hypertrophic growth (25-27).

The current data suggested that inhibition of PLC- $\beta 3$ attenuated the aortic restriction-induced activation of PKC- $\alpha$, ERK1/2 and Raf-1, which suggested that PLC- $\beta 3$ is an upstream regulator of this intracellular signal. Notably, inhibition of both $(\mathrm{P})$ RR and PLC- $\beta 3$ together produced a more profound effect on PKC- $\alpha$, ERK1/2 and Raf-1 and implied the interaction between these signals in the pathway. PLC- $\beta 3$ is considered to serve an important role in the signal transduction mechanisms of cardiac hypertrophy (28-30). The present study provided evidence for the involvement of PLC- $\beta 3$ in the signal transduction mechanism in the transcriptional and translational regulation of $\mathrm{PKC}$, ERK1/2 and Raf-1 in the heart, as gene and protein expression levels exhibited similar alteration trends. The data indicated that the inhibitory response to U73122 and HRP was likely attributed to attenuation of specific PLC- $\beta 3$ expression and subsequent activities on cardiac (P)RR. Although inhibitors of PKC and ERK1/2 were not used in this study to measure their specific responses, the inhibitory effects of U73122 and HRP observed on the expression of PKC, ERK1/2 and Raf-1 indicated that aortic restriction upregulated the expression of $(\mathrm{P})$ RR through mechanisms dependent on PLC- $\beta 3$, PKC, ERK1/2 and Raf-1 signaling pathways.

The present study confirmed the involvement of intracellular PKC, ERK1/2 and Raf-1 signals in the regulation of (P)RR expression. Furthermore, these intracellular factors may influence expression of cardiac (P)RR by administration of this receptor and PLC- $\beta 3$ inhibitors. Since PKC and ERK1/2 have been reported to be involved in myocyte hypertrophy $(31,32)$, the present findings demonstrated a similar effect for these factors in cardiomyocytes in response to high blood pressure and cardiac remodeling induced by aortic restriction.

Despite the interesting results of this study, there are still possible limitations. First, the authors primarily focused on 
A
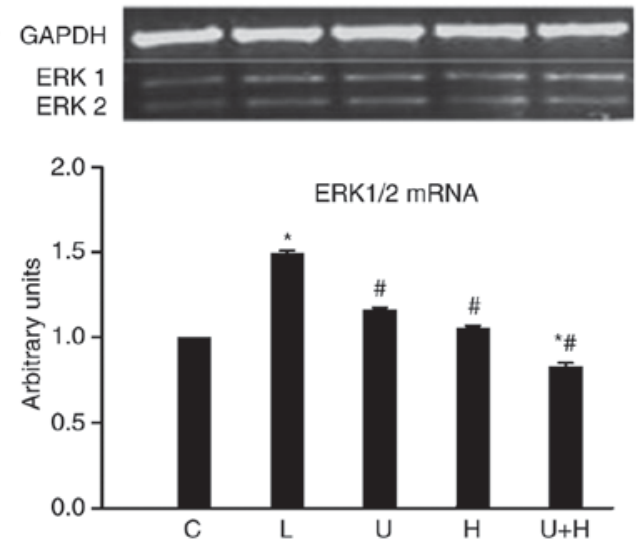

C
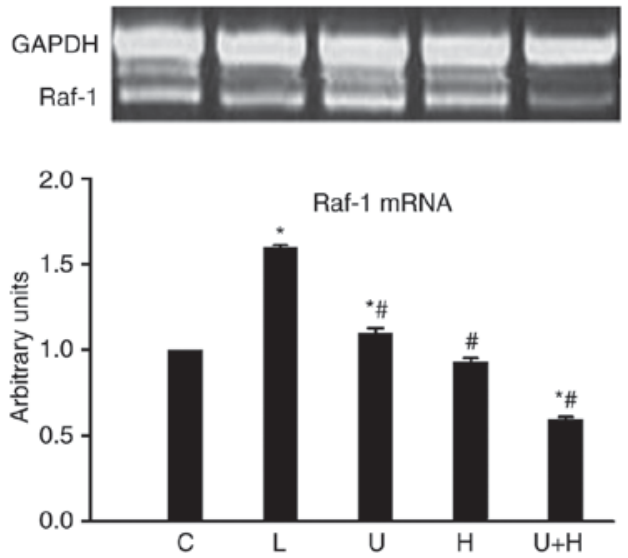

B
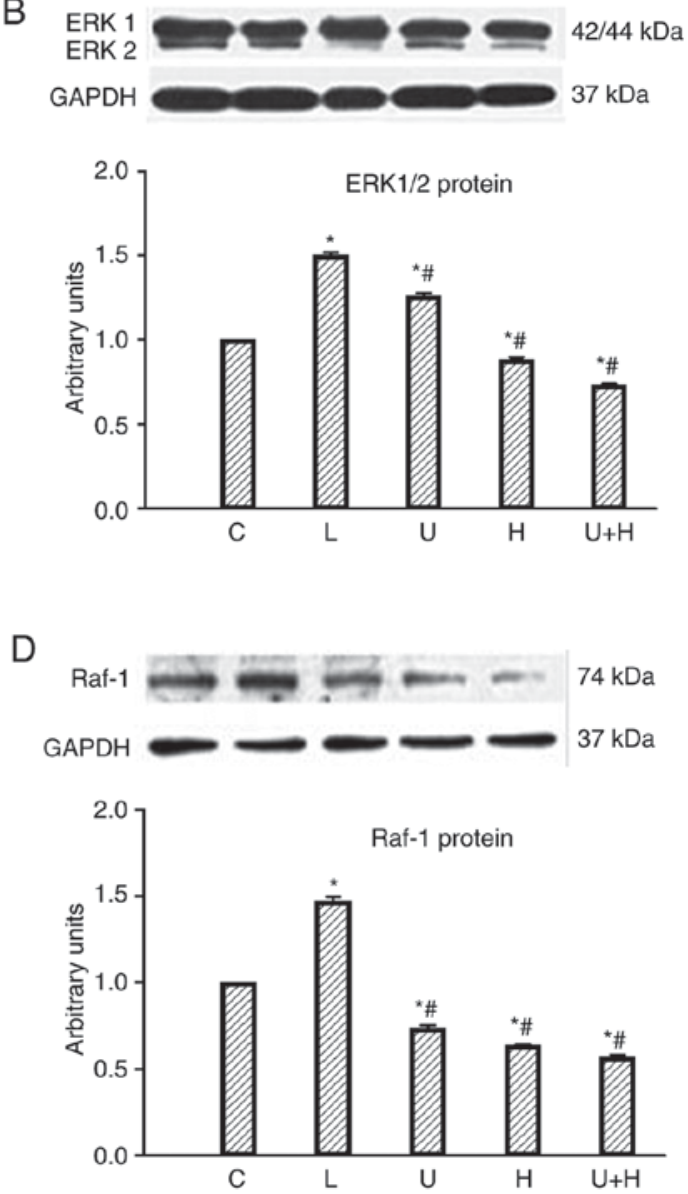

Figure 4. Levels of (A) cardiac ERK1/2 mRNA (B) and its protein, and (C) Raf-1 mRNA and (D) its protein in C (n=14), AL ( $\mathrm{n}=14)$, U (n=13), H ( $=12$ ) or $\mathrm{U}+\mathrm{H}(\mathrm{n}=13)$-treated rats. Data are expressed as the mean \pm standard error of the mean. "P<0.05 vs. control; ${ }^{*} \mathrm{P}<0.05$ vs. AL. AL, aortic ligation; ( $\left.\mathrm{P}\right) \mathrm{RR}$, (pro)renin receptor; U73122; H, handle region peptide/HRP; U+H, U73122 + HRP; C, control; ERK1/2, extracellular signal regulated kinase; Raf-1, Raf-1 proto-oncogene, serine/threonine kinase.

the effects of two drugs (HRP and U73122) on the (P)RR signaling pathway and cardiac remodeling. The authors did not test the effects of other drugs on the pathway and the heart including PKC inhibitors. However, the results of the present study established that an association was present between (P) RR, PLC- $\beta 3$ and various other signals. Secondly, fixed doses of the drugs were administered during the treatment period. Dose escalation was not conducted during the treatment period. In addition, this is the first study of its kind in which HRP and U73122 were used to test the effects of each drug and the combination of a (P)RR inhibitor and a PLC- $\beta 3$ inhibitor. Based on this study, further studies should be conducted with more animal models.

In conclusion, the results of the present study demonstrated that $(\mathrm{P}) \mathrm{RR}$ and PLC- $\beta 3$ genes together with PKC, ERK1/2 and Raf-1 are upregulated in the heart in hypertensive rats induced by aortic restriction. The (P)RR and PLC- $\beta 3$ were reduced in the heart tissue on administration of their inhibitors. In addition, PKC- $\alpha$, ERK1/2 and Raf-1 were downregulated. It is likely that the elevation of (P)RR expression induced by aortic restriction was due to the PLC- $\beta 3$ activation and subsequent signal transduction events through PKC-ERK1/2-Raf-1 signaling. Ang II may initiate cardiac hypertrophy and enhance PLC- $\beta 3$ and ERK1/2 $(33,34)$, as well as increase the expression of Raf-1. Therefore, the results suggested that $(\mathrm{P})$
RR-PLC- 33 -PKC-ERK1/2-Raf-1 signaling can be considered as an important signaling pathway of (P)RR in the heart and may therefore constitute novel therapeutic targets for the prevention and treatment of cardiac hypertrophy.

\section{Acknowledgements}

Not applicable.

\section{Funding}

The present study was supported by Science and Technology Department of Shandong Province (grant no. 2016GSF201207) and the National Natural Science Foundation of China (grant no. 81270336).

\section{Availability of data and materials}

The analyzed datasets generated during the study are available from the corresponding author on reasonable request.

\section{Authors' contributions}

YZ designed the present study, and wrote and revised the manuscript. JW, CZ and JZ performed the experiments. CL, 
AZ and AL analyzed the data. All authors have read and approved the final manuscript.

\section{Ethics approval and consent to participate}

All animal experiments were performed in accordance with the NIH guidelines (Guide for the Care and Use of Laboratory Animals) and were approved by the Animal Ethics Committee of Taishan Medical University (Taian, China).

\section{Patient consent for publication}

Not applicable.

\section{Competing interest}

The authors declare that they have no competing interest.

\section{References}

1. De Mello WC: Novel aspects of angiotensin II action in the heart Implications to myocardial ischemia and heart failure. Regul Pept 166: 9-14, 2011.

2. Ainscough JF, Drinkhill MJ, Sedo A, Turner NA, Brooke DA, Balmforth AJ and Ball SG: Angiotensin II type-1 receptor activation in the adult heart causes blood pressure-independent hypertrophy and cardiac dysfunction. Cardiovasc Res 81: 592-600, 2009.

3. Dang MQ, Zhao XC, Lai S, Wang X, Wang L, Zhang YL, Liu Y, Yu XH, Liu Y, Li HH and Xia YL: Gene expression profile in the early stage of angiotensin II-induced cardiac remodeling: A time series microarray study in a mouse model. Cell Physiol Biochem 35: 467-476, 2015.

4. Yang J, Zhu HH, Chen GP, Ye Y, Zhao CZ, Mou Y and Hu SJ: Inhibition of farnesyl pyrophosphate synthase attenuates angiotensin II-induced cardiac hypertrophy and fibrosis in vivo. Int J Biochem Cell Biol 45: 657-666, 2013.

5. Chan SH and Chan JY: (Pro)renin receptor as a therapeutic target for the treatment of hypertension? Hypertension 65: 278-279, 2015.

6. Oshima Y, Morimoto S and Ichihara A: Roles of the (pro)renin receptor in the kidney. World J Nephrol 3: 302-307, 2014.

7. Gonzalez AA, Luffman C, Bourgeois CR, Vio CP and Prieto MC: Angiotensin II-independent upregulation of cyclooxygenase- 2 by activation of the (Pro)renin receptor in rat renal inner medullary cells. Hypertension 61: 443-449, 2013.

8. Burcklé CA, Jan Danser AH, Müller DN, Garrelds IM, Gasc JM, Popova E, Plehm R, Peters J, Bader M and Nguyen G: Elevated blood pressure and heart rate in human renin receptor transgenic rats. Hypertension 47: 552-556, 2006.

9. Danser AH: (Pro)renin receptors: Are they biologically relevant? Curr Opin Nephrol Hypertens 18: 74-78, 2009.

10. Kaneshiro Y, Ichihara A, Sakoda M, Takemitsu T, Nabi AH, Uddin MN, Nakagawa T, Nishiyama A, Suzuki F, Inagami T and Itoh H: Slowly progressive, angiotensin II-independent glomerulosclerosis in human (pro)renin receptor-transgenic rats. J Am Soc Nephrol 18: 1789-1795, 2007.

11. Alcazar O, Cousins SW, Striker GE and Marin-Castano ME: (Pro)renin receptor is expressed in human retinal pigment epithelium and participates in extracellular matrix remodeling. Exp Eye Res 89: 638-647, 2009.

12. Sakoda M, Ichihara A, Kaneshiro Y, Takemitsu T, Nakazato Y, Nabi AH, Nakagawa T, Suzuki F, Inagami T and Itoh H: (Pro) renin receptor-mediated activation of mitogen-activated protein kinases in human vascular smooth muscle cells. Hypertens Res 30: 1139-1146, 2007.

13. Ichihara A, Kaneshiro Y, Takemitsu T, Sakoda M, Suzuki F, Nakagawa $\mathrm{T}$, Nishiyama $\mathrm{A}$, Inagami $\mathrm{T}$ and Hayashi $\mathrm{M}$ : Nonproteolytic activation of prorenin contributesto development of cardiac fibrosis in genetic hypertension. Hypertension 47: 894-900, 2006.

14. Feldt S, Maschke U, Dechend R, Luft FC and Muller DN: The putative (pro)renin receptor blocker HRP fails to prevent (pro) renin signaling. J Am Soc Nephrol 19: 743-748, 2008.
15. Lu X, Danser AH and Meima ME: HRP and prorenin: Focus on the (pro)renin receptor and vacuolar H+-ATPase. Front Biosci (Schol Ed) 3: 1205-1215, 2011.

16. Zhang Y, Li B, Wang B, Zhang J, Wu J and Morgan T: Alteration of cardiac ACE2/Mas expression and cardiac remodelling in rats with aortic constriction. Chin J Physiol 57: 335-342, 2014.

17. Zhang Y, Ma L, Wu J and Chen T: Hydronephrosis alters cardiac ACE2 and Mas receptor expression in mice. J Renin Angiotensin Aldosterone Syst 16: 267-274, 2015.

18. Zhang Y, Wu J, Zhang Z, Wang B, Chen P and Jing X: Effect of low sodium intake and $\beta$-blockade on renin synthesis and secretion in mice with unilateral ureteral ligation. Hypertens Res 33: 1258-1263, 2010 .

19. Connelly KA, Advani A, Kim S, Advani SL, Zhang M, White KE, Kim YM, Parker C, Thai K, Krum H, et al: The cardiac (pro)renin receptor is primarily expressed in myocyte transverse tubules and is increased in experimental diabetic cardiomyopathy. J Hypertens 29: 1175-1184, 2011.

20. Hirose T, Mori N, Totsune K, Morimoto R, Maejima T, Kawamura T, Metoki H, Asayama K, Kikuya M, Ohkubo T, et al: Gene expression of (pro)renin receptor is upregulated in hearts and kidneys of rats with congestive heart failure. Peptides 30: 2316-2322, 2009.

21. Nguyen G, Delarue F, Burcklé C, Bouzhir L, Giller T and Sraer JD: Pivotal role of the renin/prorenin receptor in angiotensin II production and cellular responses to renin. J Clin Invest 109: 1417-1427, 2002.

22. Saris JJ, Hoen PA, Garrelds IM, Dekkers DH, den Dunnen JT, Lamers JM and Jan Danser AH: Prorenin induces intracellular signaling in cardiomyocytes independently of angiotensin II. Hypertension 48: 564-571, 2006.

23. Cousin C, Bracquart D, Contrepas A and Nguyen G: Potential role of the (pro)renin receptor in cardiovascular and kidney diseases. J Nephrol 23: 508-513, 2010.

24. Nguyen G and Muller DN: The biology of the (pro)renin receptor. J Am Soc Nephrol 21: 18-23, 2010.

25. Makary S, Voigt N, Maguy A, Wakili R, Nishida K, Harada M, Dobrev D and Nattel S: Differential protein kinase C isoform regulation and increased constitutive activity of acetylcholine-regulated potassium channels in atrial remodeling. Circ Res 109: 1031-1043, 2011.

26. Otani $\mathrm{H}$, Yoshioka $\mathrm{K}$, Nishikawa $\mathrm{H}$, Inagaki $\mathrm{C}$ and Nakamura $\mathrm{T}$ : Involvement of protein kinase $\mathrm{C}$ and $\mathrm{RhoA}$ in protease-activated receptor 1-mediated $\mathrm{F}$-actin reorganization and cell growth in rat cardiomyocytes. J Pharmacol Sci 115: 135-143, 2011.

27. Palfi A, Bartha E, Copf L, Mark L, Gallyas F Jr, Veres B, Kalman E, Pajor L, Toth K, Ohmacht R and Sumegi B: Alcohol-free red wine inhibits isoproterenol-induced cardiac remodeling in rats by the regulation of Akt1 and protein kinase C alpha/beta II. J Nutr Biochem 20: 418-425, 2009.

28. Atef ME and Anand-Srivastava MB: Enhanced expression of Gq $\alpha$ and PLC- $\beta 1$ proteins contributes to vascular smooth muscle cell hypertrophy in SHR: Role of endogenous angiotensin II and endothelin-1. Am J Physiol Cell Physiol 307: C97-C106, 2014.

29. Zhang L, Malik S, Pang J, Wang H, Park KM, Yule DI, Blaxall BC and Smrcka AV: Phospholipase C $\varepsilon$ hydrolyzes perinuclear phosphatidylinositol 4-phosphate to regulate cardiac hypertrophy. Cell 153: 216-227, 2013 .

30. Woodcock EA, Grubb DR and Iliades P: Potential treatment of cardiac hypertrophy and heart failure by inhibiting the sarcolemmal binding of phospholipase Cbetalb. Curr Drug Targets 11: 1032-1040, 2010.

31. Singal T, Dhalla NS and Tappia PS: Regulation of c-Fos and c-Jun gene expression by phospholipase $\mathrm{C}$ activity in adult cardiomyocytes. Mol Cell Biochem 327: 229-239, 2009.

32. Singal T, Dhalla NS and Tappia PS: Reciprocal regulation of transcription factors and PLC isozyme gene expression in adult cardiomyocytes. J Cell Mol Med 14: 1824-1835, 2010.

33. Schnabel P, Mies F, Nohr T, Geisler M and Böhm M: Differential regulation of phospholipase C-beta isozymes in cardiomyocyte hypertrophy. Biochem Biophys Res Commun 275: 1-6, 2000.

34. Bai H, Wu LL, Xing DQ, Liu J and Zhao YL: Angiotensin II upregulation of $\mathrm{G}$ alpha $\mathrm{q} / 11$, phospholipase $\mathrm{C}$ beta 3 and extracellular signal-regulated kinase 1/2 via angiotensin II type 1 receptor. Chin Med J (Engl) 117: 88-93, 2004. 